\title{
In vitro maturation (IVM) as a new technique to treat polycystic ovary syndrome (PCOS) and induce pregnancy in Indonesia
}

\author{
Soegiharto Soebijanto \\ Department of Reproductive Endocrinology Obstetrics and Gynecology, Faculty of Medicine, University of Indonesia, Jakarta
}

\begin{abstract}
Abstrak
Tujuan Dilakukan penilaian terhadap keberhasilan kehamilan pada penanganan dengan In Vitro Maturation (IVM) pada kasus-kasus PCOS (Poly Cystic Ovary Syndrome) sebagai teknik yang pertama dilakukan di Indonesia.

Metode Tulisan ini merupakan laporan kasus dari teknik yang baru dikembangkan di Indonesia. Bahan penelitian adalah 7 kasus dengan PCOS yang jelas, diantaranya 1 pasien dengan riwayat OHSS (Ovary Hyper Stimulation Syndrome) pada prosedur fertilisasi in vitro sebelumnya dan 1 pasien dengan gambaran PCOS, kemungkinan hiperesponder, di Rumah Sakit Family dari bulan Januari sampai bulan Mei 2009. Induksi folikel dengan dosis minimal, primming HCG 10.000 IU pada hari ke 10 dan 40 jam kemudian dilakukan ovum pickup, selanjutnya diinseminasi dan folikel yang terbuahi dilakukan penilaian. Embrio yang bermutu baik ditransfer kedalam uterus. Penilaian kehamilan dilakukan secara biokimiawi, penilaian adanya kantung janin dan denyut jantung.
\end{abstract}

Hasil Telah dilakukan teknik IVM di RS Family, Jakarta Barat bersama dengan tim TRB RS Family pada tujuh kasus. Dari tujuh pasien ditemukan 156 folikel antral atau rata-rata 22 folikel perpasien, ditemukan 81 oosit, dan setelah dimaturasi diperoleh 61 oosit matur (75\%). Pada tiga bulan dilakukan fertilisasi in vitro dan 4 kasus dilakukan ICSI (In Cystoplasmic Sperm Infection). Pada serial kasus ini diperoleh 412 embrio, dan 22 buah embrio ditransfer, dan dari 7 kasus diperoleh 2 kehamilan (9\%).

Kesimpulan Teknik In Vitro Maturation (IVM) merupakan alternatif untuk mengatasi masalah infertilitas pada pasien PCOS dengan keunggulan risiko sindrom hiperstimulasi ovarium yang rendah serta biaya yang lebih murah. (Med $\boldsymbol{J}$ Indones 2009; 18: 269-75)

\begin{abstract}
Aim To assesse the success of inducing pregnancies in the treatment of PCOS (Poly Cystic Ovary Syndrome) cases with in vitro maturation as a newly application technique in Indonesia.

Methods This paper is a report of 7 cases in Indonesia that used the newly developed technique. There were 7 cases confirmed PCOS, in which 1 patient with a history of OHSS (Ovary Hyper Stimulation Syndrome) in a previous IVF procedure and 1 patient with PCOS characteristics, suspected hyper responder, in the Family Hospital from January to May of 2009. Follicular induction was performed with a minimum dose, primming with HCG 10.000 IU, on the 10th day and 40 hours later ovum pick up was performed, followed by in vitro maturation. Subsequently, insemination was performed and the inseminated follicle was assessed. Well qualified embryos then transferred them into the uterus. We then performed assessment of pregnancy biochemically, by the presence of embryonic sac and embryonic heart beat.

Results We have performed the IVM (In Vitro Maturation) technique in the Family Hospital, West Jakarta, along with the TRB team of the Family Hospital in seven PCOS cases. From these patients, we have found 156 antral follicles (average of 22 follicles per patient), 82 oocytes, and after maturation, 61 mature oocytes (75\%). In three cases, in vitro fertilization was performed, while in 4 cases ICSI (In Cystoplasmic Sperm Infection) was performed. In these serial cases we obtained 41 embryos, and 22 fertilized embryos were transferred. Of 7 cases, we achieved two successful pregnancies (29\%).
\end{abstract}

Conclusion In vitro maturation is an alternative procedures in solving infertility problems for PCOS patients with lower risk of OHSS and more cost effective than conventional IVF. (Med J Indones 2009; 18: 269-75)

Key words: pregnancy, PCOS, in vitro maturation 
Compared to normal women, PCOS have a larger tendency to catch the side effect of OHSS. It is believed that the stimulation of ovulation may induce ovarian and endometrial cancer. ${ }^{1}$ Besides, stimulation with gonadotropin and GnRH agonist can be costly. ${ }^{2}$

Many scientists have performed IVF (in vitro fertilization) in the normal cycle because of the simplicity of the method, limited side effects, low cost and considering the patient's comfort. Although the normal cycle provides limited success due to the low number of oocytes gained, the success rate of pregnancy is $46 \%$ after the procedure has been repeated 4 times. ${ }^{3}$ Therefor, it has been considered to perform the IVF technique in the normal cycle with in vitro maturation. By this way, even without costly stimulation the patient still has a good chance of achieving pregnancy.

Nonetheless, this technique should only be applied in certain cases considering the specific conditions of each case, to optimize the success of pregnancy. Further research must be performed to find the optimum conditions for cultivation to improve the implantation rate of oocytes that are matured in vitro.

This article will describe the experience of performing the IVM program in PCOS cases and predicted hyperresponders.

The IVM technique was first developed in $1940 .{ }^{4}$ It was performed until 1960 when a technique was develop to obtain an oocyte from a de Graaf follicle through laparoscopy. ${ }^{5}$

Cha in 1991, and Trounson in 1994, announced the success of achieving pregnancy through IVM in PCOS cases. ${ }^{6,7}$ PCOS patients are good candidates for IVM because of the number of antral follicles in this case group. In general, 30 to $35 \%$ of PCOS patients will achieve and 10 to $15 \%$ in PCOS patients. ${ }^{8,9}$

Thus, IVM was performed to lower costs, to prevent OHSS in PCOS patients, and to simplify the procedure of IVF. ${ }^{10,11}$

\section{METHODS}

All the cases were collected in the Family Hospital, Jakarta from April 2008 to April 2009. This is a preliminary report of a prospective study, assessing the rate of in vitro maturation, fertilization, the formation of embryo, and ultimately, pregnancy.

The cases used in this study were 7 infertility cases with PCOS, established through the Rotterdam criteria, and one case with a history of OHSS (ovarian hyperstimulation syndrome). HSG was performed to observe uterine cavity in cycle before the program was started.

Hormonal measurements were taken for FSH, LH, E2 and testosterone. On the sexual partner we performed sperm analysis and sperm recovery test. We injected the patient with gonadotropin $150 \mathrm{IU}$ in days 8, 9, and 10 of the menstrual cycle, and priming with HCG 10.000 IU. On the 11th day and 40 hours later we performed OPU (Ovum Pick Up)

During OPU we measured the diameter of the follicle. OPU was performed using a combination of size $19 \mathrm{~g}$ aspiration needle and a set of aspiration needles with the outer needle sized $17 \mathrm{~g}$ and inner needle sized $20 \mathrm{~g}$ with a suction pressure of 80 to $110 \mathrm{mmHg}$.

\section{Basic USG}

USG was performed on the second day of the menstrual cycle to observe the uterus and to determine the number of BAF (basal antral follicle) in both ovaries. If the patient has an irregular cycle, then progesteron preparation (Provera $5 \mathrm{mg}$, twice daily for five days) was used to induce menstruation.

The next USG was performed on the 6th and 9th days to measure the thickness of the endometrium and to ensure the presence of a developing follicle. (Figure1)

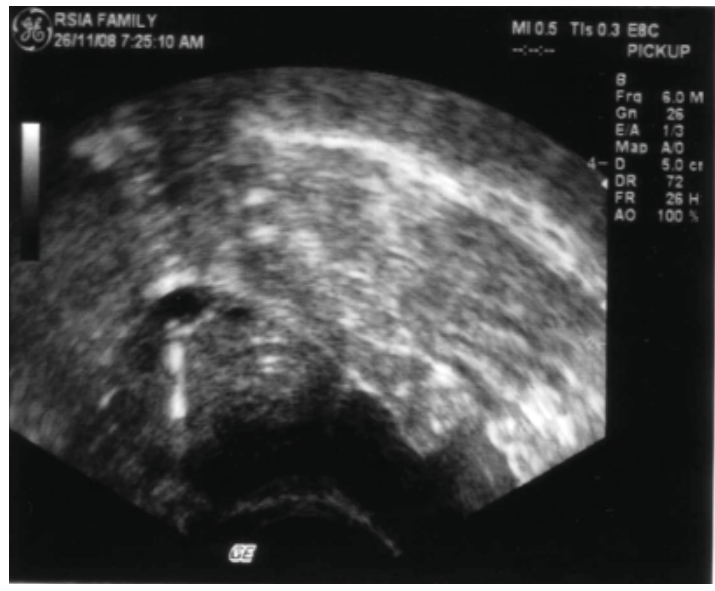

Figure 1: USG of Antral Follicle

Injections of 150 IU gonadotropin was given to the patients on days 8,9 , and 10 . On the 11th day, we gave an injection of 10.000 IU HCG. In the case of the hyperresponder whose follicle was $11 \mathrm{~mm}$ on the 9th day, HCG priming was performed on the 10th day. 


\section{HCG Administration}

Patients were given 10.000 IU hCG 36 hours prior to OPU. OPU was performed between day 10-14, depending on the endometrial thickness (must be $6 \mathrm{~mm}$ or more) and the follicular diameter. This is very important to prevent spontaneous ovulation.

\section{OPU (Ovum pick up)}

One day before the OPU, a medium was prepared: Synvitro fluch, LAG, IVM, FSH solution, hCG solution, stored in $37^{\circ}$ Celcius and $5 \% \mathrm{CO}_{2}$. Obtained oocytes were incubated in LAG medium for 2 to 3 hours, then transferred to final IVM maturation medium, consisted of IVM medium, patient serum, and FSH solution. hCG solution was incubated for 24 to 48 hours. The next day, the oocyte was denuded, then stored at ISM1 medium for 2 hours. Oocytes that fulfill requirements underwent ICSI (intracytoplasmic sperm injection).

The needles used for OPU were a combination of size $19 \mathrm{~g}$ aspiration needle and a set of aspiration needles, outer 17 g needle, inner 20 g needle, with a suction pressure of 80 to $110 \mathrm{mmHg}$. All visible follicles were extracted while the patient underwent general anesthesia.

\section{Method of locating oocytes}

Follicular solution was transferred to a petri dish then examined under a stereo miscroscope. Follicular solution was strained through a cellular sieve of $70 \mathrm{um}$, then diluted by a washing solution, then transferred to a petri dish (falcon $60 \times 15 \mathrm{~mm}$ ). All procedures were performed on a plate of $37^{\circ} \mathrm{C}$.

\section{Maturation procedure of oocyte ${ }^{12,13,14}$}

Medium was prepared at least one hour ahead of OPU and placed in an incubator of $30^{\circ} \mathrm{C}$. Three petri dishes were required (falcon $35 \times 10 \mathrm{~mm}$ ) consisting of 2-2,5 $\mathrm{ml}$ of oocyte washing solution under mineral oil for each patient. For each patient, we also prepared, $50 \mathrm{ml}$ Falcon filled with 25-50 ml of oocyte washing solution in an incubator. The oocytes were then gathered in a 10 $\mathrm{ml}$ tube filled with washing medium mixed with 2-3 ml. 2 $\mathrm{IU} / \mathrm{ml}$ heparin. Other than the usual medium, we also used $0,9 \% \mathrm{NaCl}$ mixed with $2 \mathrm{IU} / \mathrm{ml}$ of heparin.

Immature oocytes were incubated in a tissue culture dish (falcon $60 \times 15 \mathrm{ml}$, consisting of $1 \mathrm{ml}$ maturation medium with a final concentration of $75 \mathrm{mIU} / \mathrm{ml}$ of FSH and $75 \mathrm{mIU} / \mathrm{ml}$ of $\mathrm{LH}$ in $30^{\circ} \mathrm{C}$ with a flow of $5 \%$
CO2 and 95\% air or of three gasses $90 \%$ N2, $5 \%$ CO2, and $5 \%$ O2 with a humidity of $100 \%$. This medium was prepared at least 2 years prior to OPU.

Ovum pick up was performed 40 hours after hCG administration under general anesthesia. OPU was performed using COOK ovum aspiration needle size $19 \mathrm{~g}$ or COOK ovum aspiration needle set consisting of $17 \mathrm{~g}$ outer needle and $20 \mathrm{~g}$ inner needle. (Figure 2 and 3)

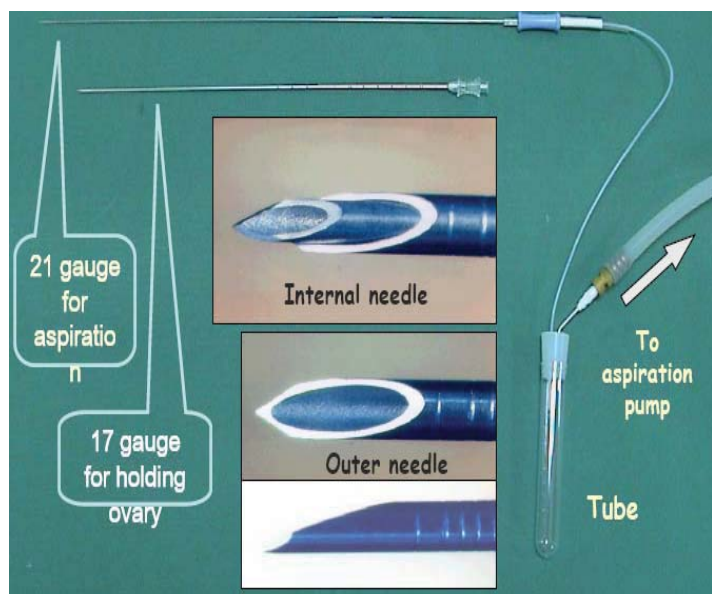

Figure 2. Ovum pick up needle ${ }^{16}$

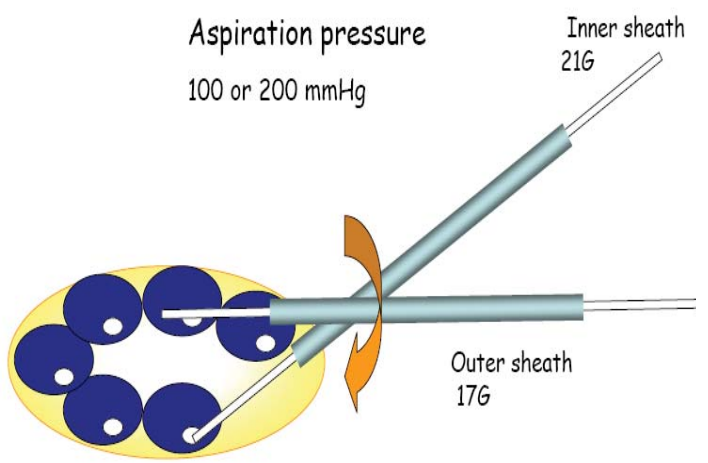

Figure 3. clockwise OPU to Ovary ${ }^{15}$

Needle selection depends on the condition of the follicle. In patients with a history of OHSS and hyperresponder, where the diameter of most follicles were 9 to $11 \mathrm{~mm}$, we used a $19 \mathrm{~g}$ needle. But in patients with PCOS, in which most of the diameter of follicles were 6 to $8 \mathrm{~mm}$, we used a needle set of $17 \mathrm{~g}$ and $21 \mathrm{~g}$ needles. In the latter condition, the follicles were first punctures with the $17 \mathrm{~g}$ outer needle to the adjacent of the target 
follicle, then the $21 \mathrm{~g}$ inner needle was inserted into the follicle and the follicular solution was aspirated. For the next follicle, the inner needle was then retracted into the outer needle that was manipulated in such a way that it reaches the side of the next follicle.

In cases where the vaginal walls were considered thick and rigid, we used the outer and inner needle set, because the $19 \mathrm{~g}$ needle was very pliable making it difficult to puncture the vaginal wall. During perforation, pressure to the abdominal wall was applied by a nurse to help fixate the ovary.

Rinsing of the needles, or tubing, after two or three aspirations of the follicular solution was very important. Rinsing was performed by using $\mathrm{NaCl}$ solution mixed with heparin to prevent coagulation in the lumen of the needle. Aspirated solutions were immediately brought to the laboratory to observe for oocyte cumulus complex. (Figure 4,5, and 6)

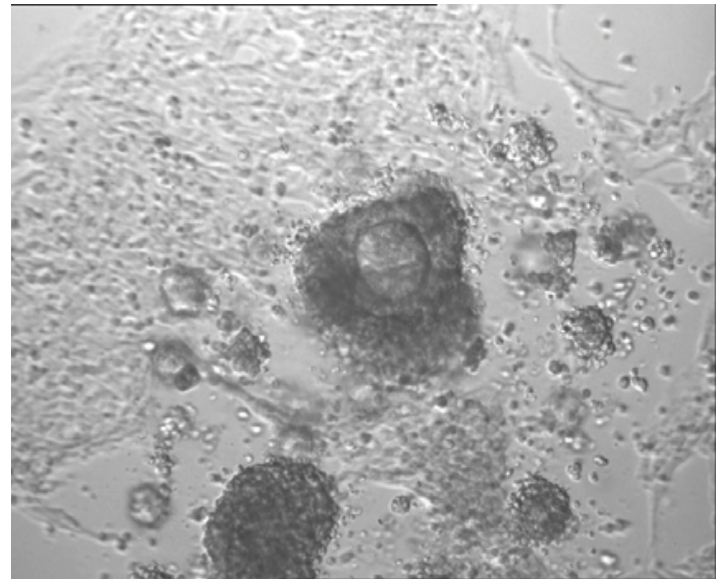

Figure 4. oocyte cumulus complex

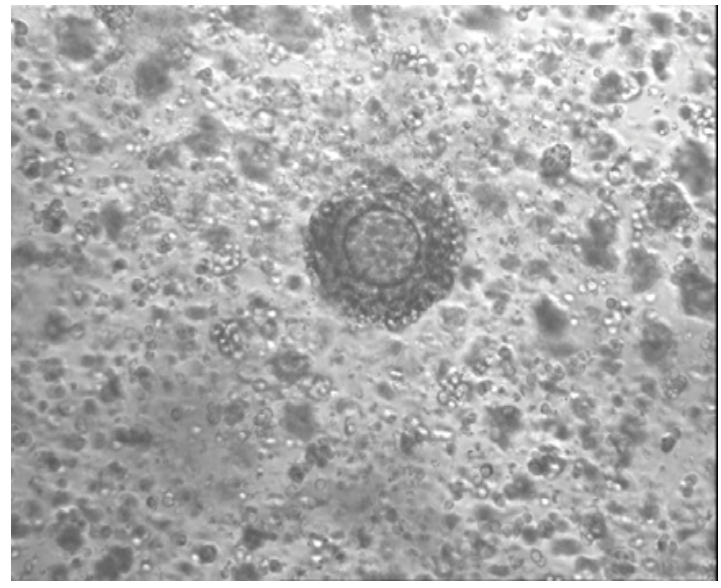

Figure 5. Immature oocyte

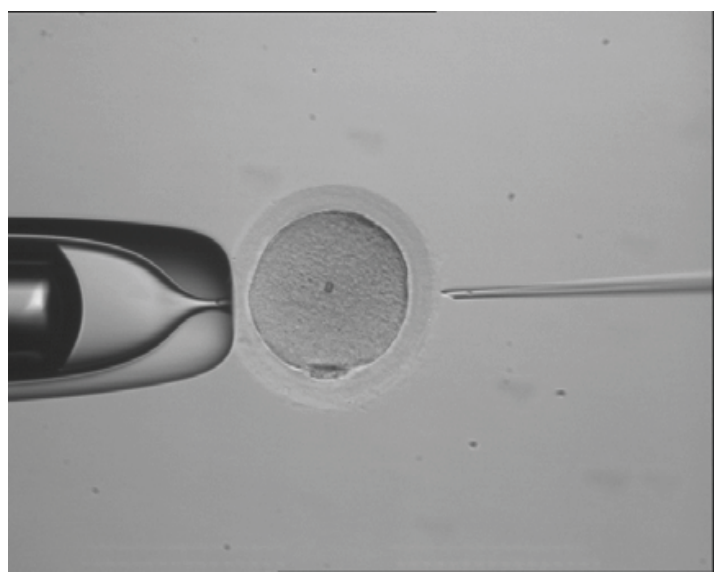

Figure 6. intra cytoplasmic sperm injection

\section{RESULTS}

The first patient, 31 years old, has been infertile for 8 years and has underwent induction of ovulation 8 times, and failed. Physical examination showed body weight $88 \mathrm{~kg}$, height $160 \mathrm{~cm}$, BMI 34.5, with signs of hirsutism. Ultrasonographic examination on the second day of menstruation showed: uterus within normal limits, 40 basal antral follicles (BAF) in both ovaries. Hormonal examination results showed: FSH $4,5 \mathrm{mIU} / \mathrm{ml}$, LH 3,0 mIU/ml, E2 $<20 \mathrm{pg} / \mathrm{ml}$ dan testoterone 3,8 ng/ dl. Sperm analysis of the husband were within normal range with sperm recovery of 10 million/ml.

Out of 11 mature oocytes that underwent ICSI, 8 were fertilized, and developed into 8 embryos. Four days after OPU we transferred 4 embryos. The patient did not become pregnant and menstruated.

The second patient was 30 years old, with a history of blighted ovum three years before. Screening revealed a non patent right tube and appearance of policystic ovaries with more than 20 BAFs. Hormonal examination showed FSH 6,0 mIU/ml , LH 3,9 mIU/ml, E2 <20 pg/ $\mathrm{ml}$. Sperm analysis of the husband were within normal range with sperm recovery of 4.5 million $/ \mathrm{ml}$. Upon OPU the follicle was $7.4 \mathrm{~mm}$ to $12 \mathrm{~mm}$ in diameter. In this patients we obtained 9 immature oocytes and retained 8 oocytes post maturation that were viable for ICSI. Fertilization occured in 5 oocytes and developed into 3 embryos of excellent quality. The three embryos were transferred and given luteal support with vaginal progesteron. The patient became pregnant with one gestational sac, an apparent yolk sac, fetal pole and pulsation. (Figure 7) 


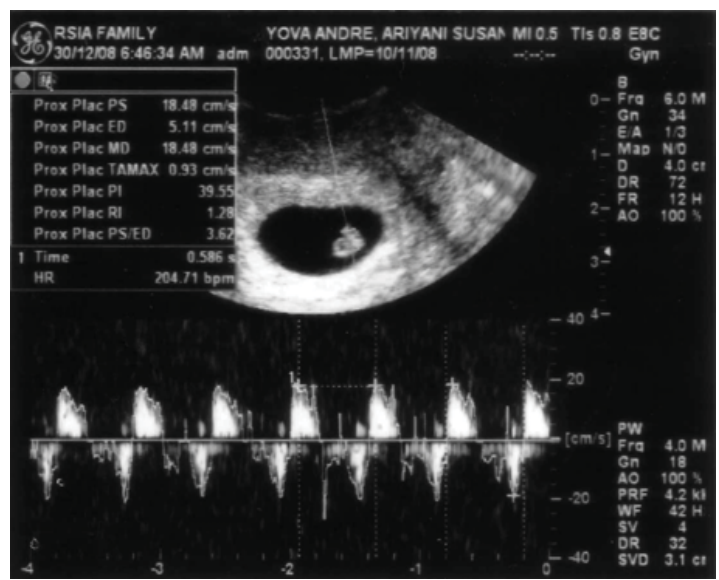

Figure 7. gestational sac, yolk sac and blood flow in the pregnant case

The third patient was 42 years old with a history of OHSS in a previous IVF procedure, the patient did become pregnant but miscarried. Upon examination on the second day of menstruation we found 11 BAFs. Sperm analysis of the husband showed a sperm count of less than $100.000 \mathrm{ml}$. Upon OPU we obtained $7 \mathrm{im}$ mature oocytes, to which we induced maturation. Upon maturation, we obtained 6 oocytes that were adequate for ICSI. Fertilization occured in 4 oocytes and developed into 4 embryos. Three embryos were transferred and given luteal phase support with vaginal progesteron. The patient failed to be pregnant.

The fourth patient was 31 year old with a history of abortion. Screening revealed 16 BAFs (PCO), FSH 6,2 $\mathrm{mIU} / \mathrm{ml}, \mathrm{LH} 5,4 \mathrm{mIU} / \mathrm{ml}$, E2 23,2 pg/ml. Sperm analysis of the husband revealed sperm recovery of less than $100.000 \mathrm{ml}$. Upon OPU, the follicular diameter was 5 $\mathrm{mm}$, and to $12 \mathrm{~mm}$. From this patients we obtained 19 oocytes, and 13 oocytes post-maturation that were adequate for ICSI. Out of those, 12 oocytes became fertilized and 11 developed into embryos. Four embryos were frozen and three were transferred and given luteal support using vaginal progesteron. The attempt for pregnancy was not successful.

The fifth patient was 28 year old with 4 years of primary infertility and a history of failed IVF. Screening revealed bilateral non patent tubes and the appearance of PCO ovaries with 25 BAFs. Sperm analysis of the husband were within normal range with sperm recovery of 3 million/ml. From this patients we obtained 13 immature oocytes, performed maturation, and obtained 12 oocytes ready for ICSI. Fertilization occured in 8 oocytes and 7 of them developed into embryos. Two embryos were transferred. The patient was pregnant and fetal pulsation was recorded on the 6th week of pregnancy.
The sixth patient was 31 years old, with a history of four failed IVFs. The second IVF was successful but was a $\mathrm{BO}$ and the latest IVF showed signs of OHSS. The patient had two non patent tubes. After ICSI four oocytes were fertilized and three embryos developed. These three were tranferred, but the patient failed to be pregnant.

The seventh patient was 31 year old who previously had been pregnant but miscarried. She has been married for three years, and has a menstrual cycle of 36 to 48 days. Sperm analysis were within normal limits with sperm recovery of 2 million/ml. We counted 24 BAFs. Upon OPU the follicular diameter was to $9 \mathrm{~mm}$. In this patient we obtained 7 immature oocytes on which we performed maturation. Post maturation we obtained 7 oocytes that were ready for ICSI. Post ICSI, three oocytes were fertilized and developed into 3 embryos. These three were transferred, but the patient failed to be pregnant

\section{DISCUSSION}

Table 1 shows that out of the seven patients who received the IVM procedures, two patients had obvious PCOS, 1 patient with a history of OHSS in a previous IVF procedure. Although hormonally there were no obvious signs of PCOS (less than $23.2 \mathrm{pg} / \mathrm{ml}$ ), all patients had BAF (more than 11) and all patients fulfilled the Rotterdam criteria. These are typical of hyperresponders who run the risk of developing OHSS once stimulated through the usual protocol (long or short protocol).

Out of the seven spouses, two cases were oligospermia. Totally in this series there were 156 BAFs, with a mean of 22 follicles and a mean of 12 oocytes. This meant that the OPU was successful in $56 \%$ of the cases, which was quite a feat considering that the follicular diameters were between 5.3 to $10 \mathrm{~mm}$, and that this was the first OPU attempt on smaller follicles.

Out of 59 mature oocytes, all underwent ICSI, from which 41 (69\%) embryos developed. Out of 7 patients who received transfer, two (28.6\%) became pregnant. Although the population size is yet to be expanded, this is an encouraging preliminary compared to the achievements of other countries. Results from other countries based on the cilinical pregnancy rates were: France 18\%, Japan 26.8\%, Scandinavia (Sweden and Finland) 22\%, Vietnam $27.6 \%$ and Canada 28\%. ${ }^{15,16}$ Out of 81 oocytes that were matured in vitro, we harvested 59 (73 \%) mature oocytes. This shows that the in vitro maturation technique was quite successful. 
Table 1. Characteristic patients and results of IVM

\begin{tabular}{|c|c|c|c|c|c|c|c|c|}
\hline \multirow{2}{*}{ No } & \multirow{2}{*}{ Condition } & \multicolumn{7}{|c|}{ Patients No. } \\
\hline & & $\overline{1}$ & 2 & 3 & 4 & 5 & 6 & 7 \\
\hline 1 & Age (years) & 34 & 30 & & 31 & 28 & 31 & 31 \\
\hline 2 & Length of infertility (years) & 8 & 3 & & & 4 & & 3 \\
\hline 3 & Weight (kg) & 88 & & & & & & \\
\hline 4 & $\operatorname{BMI}\left(\mathrm{kg} / \mathrm{m}^{2}\right)$ & 34,5 & & & & & & \\
\hline 5 & Hirsutism & + & & & & & & \\
\hline 6 & BAF (n) & 40 & 20 & 11 & 16 & 25 & 20 & 24 \\
\hline 7 & FSH $(\mathrm{miv} / \mathrm{ml})$ & 4,5 & 6 & 8,4 & 6,2 & $5,3,24$ & 9,4 & 5,5 \\
\hline 8 & LH (miv/ml) & 3 & 3,9 & 7,9 & 5,4 & 3,2 & 6,0 & 2,2 \\
\hline 9 & $\mathrm{E} 2(\mathrm{vg} / \mathrm{ml})$ & $<20$ & $<20$ & 22,8 & 23,2 &, 10 & $<20$ & $<20$ \\
\hline 10 & Testostelone & $3,8 \mathrm{ng}$ & & & & & & \\
\hline 11 & Sperm (million /ml) & 10 million & 4,5 million & 100.000 & 100.000 & 3 million & 8 million & 2 million \\
\hline 12 & Induksi & 150 & 150 & 150 & 150 & 150 & 150 & 150 \\
\hline 13 & hCG (iv) & 10.000 & 10.000 & 10.000 & 10.000 & 10.000 & 10.000 & 10.000 \\
\hline 14 & Smallest fol (mm) & 5,3 & 7,4 & & 5 & 6 & 7 & 5 \\
\hline 15 & Largest fol (mm) & 10,6 & 12 & & 12 & 10 & 10 & 9 \\
\hline 16 & Immature oocytes (n) & 20 & 9 & 7 & 19 & 13 & 6 & 7 \\
\hline 17 & Mature oocytes (n) & 11 & 8 & 6 & 13 & 12 & 4 & 7 \\
\hline 18 & Embryos (n) & 8 & 5 & 4 & 11 & 7 & 3 & 3 \\
\hline 19 & Transferred (n) & 4 & 3 & 3 & 4 & 2 & 3 & 3 \\
\hline 20 & Frozen embryos (n) & 4 & 2 & - & 7 & 5 & - & - \\
\hline 21 & Pregnant & - & + & - & - & + & - & - \\
\hline 22 & Miscarriage & - & + & & & - & & \\
\hline
\end{tabular}

This finding showed that IVM as an IVF (In Vitro Fertilization) procedure was successfully performed in Indonesia. In the future, IVM will be the first choice for patients who are willing to undergo reproductive technology, for the following reasons: 1) simplified procedure; 2) cost efficiency; 3) avoidance of OHSS.

Other advantages of IVM are the preservation of oocytes or ovarian tissue in cancer cases, more comfortable for the patient because it is less pain due to injections and the less frequent monitoring of hormonal levels in the blood. Also, it reduces the trauma of having to endure OHSS in previous IVFs. (Tabel 2)

\section{Acknowledgment}

We are especially grateful to the team of Family Hospital (dr. Muchsin Jaffar, dr. Hadi Syarbaini and dr. Yuslam Edi Fidianto) who have given great assistance in producing this article.
Table 2. Results of maturation, fertilization, embryo development and pregnancy.

\begin{tabular}{ll}
\hline \multicolumn{1}{c}{ Description } & \multicolumn{1}{c}{$\mathrm{n}(\%)$} \\
\hline Follicular puncture & 156 \\
Oocyte cummulus complex & $81(52 \%)$ \\
Mature oocyte & $61(75 \%)$ \\
ICSI & \\
$\quad$ Oocyte & 59 \\
$\quad$ Fertilization & $41(69 \%)$ \\
$\quad$ Embryo ( good) & $22(54 \%)$ \\
Conventional IVF & \\
$\quad$ Oocyte & 3 \\
Fertilization & 0 \\
\hline
\end{tabular}




\section{REFFERENCES}

1. Nargund G, Waterstone J, Bland J, Philips Z, Parsons J and Campbell S Cumulative conception and live birth rates in natural (unstimulated) IVF cycles.Hum Reprod 2001; 16:259-62

2. Tarlatzis BC, Grimbizis G, Bontis J, Mantalenakis S. Ovarian stimulation and ovarian tumours: a critical reappraisal. Hum Reprod Update 1995; 1: 284-301

3. Daya S, Gunby J, Hughes EG, Collins JA, Sagle MA and YoungLai EV Natural cycles for in-vitro fertilization: costeffectiveness analysis and factors influencing utcome. Hum Reprod 1995; 10:1719-24

4. Rock J, Menkin MF. In vitro fertilization and cleavage of human ovarian eggs. Science 1946; 100: 105-7

5. Edwards RG, Bavister BD, Steptoe PC. Early stages of fertilization in vitro of human oocytes matured in vivo. Nature 1969; 221: 632-5

6. Cha KY, Koo JJ, Choi DH, Han SY, Yoon TK. Pregnancy after in vitro fertilization of human follicullar oocytes collection from non stimullated cycles, their culture in vitro and their transfer in a donor oocytes program. Fertil Steril1991;55:109-13

7. Trounson A, Wood C and Kausche A In vitro maturation and the fertilization and developmental competence of oocytes recovered from untreated polycystic ovarian patients. Fertil Steril 1994; 62:353-62

8. Donderwinkel PF, Schoot DC, Coelingh Bennink HJ and Fauser BC Pregnancy after induction of ovulation with recombinant human FSH in polycystic ovary syndrome. Lancet 1992; 340:983
9. Chian RC, Buckett WM, Tulandi T and Tan SL () Prospective randomized study of human chorionic gonadotrophin priming before immature oocyte retrieval from unstimulated women with polycystic ovarian syndrome. Hum Reprod 2000; $15: 165-7$

10. Hadi S, Muchsin J Yuslam EF, Dianing M, Soegiharto S: Laporan Kasus, Pengalaman: Kehamilan dengan In Vitro Maturation (IVM) di FFC RSIA Family. Pertemuan Ilmiah Tahunan Himpunan Fertilitas dan Endokrinologi Reproduksi Indonesia; 2009 Jan, Semarang. Indonesia.

11. Delvigne A and Rozenberg S Epidemiology and prevention of ovarian hyperstimulation syndrome (OHSS): a review. Hum Reprod Update 2002; 8:559-77

12. Cha KY, Koo JJ, Choi DH, Han SY, Yoon TK. Pregnancy after in vitro fertilization of human follicullar oocytes collection from non stimullated cycles, their culture in vitro and their transfer in a donor oocytes program. Fertil Steril 1991;55:109-13

13. Paulson RJ, Sauer MV, Francis MM, Macaso T, Lobo RA. Factors affecting pregnancy success of human in-vitro fertilization in unstimulated cycles. Hum Reprod 1994; 9: 1571

14. Chian RC, Niwa K, Sirard MA. Effect of cumulus cells present during different periods of culture on maturation in vitro of bovine oocytes. Theriogenology 1994; 41:1499-508

15. Chian RC, Demirtas E, Buckett W, Tan SL. In vitro maturation of oocytes collected from unstimulated ovaries for oocyte donation. Fertil steril 2007; 88: 62-7

16. Garry N, Piquette. The in vitro maturation (IVM) of human oocytes for in vitro fertilization (IVF) : is time yet to switch to IVM-IVF?. Fertil Steril 2006;85:516-33 
